Mini Review

\title{
A Review of Linear Gel Fracturing Fluids
}

\author{
Ramana Murthy RVV, ${ }^{1}$ Devaraju S, ${ }^{1}$ Chavali $M^{1,2,3 *}$ \\ ${ }^{1}$ Department of Sciences and Humanities, Vignan's Foundation for Science, Technology and Research University, India \\ ${ }^{2}$ Shree Velagapudi Ramakrishna Memorial College, India \\ ${ }^{3} \mathrm{NTRC}, \mathrm{MCETRC}$, India
}

\begin{abstract}
Linear gel is prepared by treating bio-diesel with various water samplescollected from different water bodies. The new biodiesel based linear gel was employed in the recovery of oil wells through hydro fracturing and pilot tests were conducted for the first time. Viscosity of gel was measured at various bottom hole-circulating temperatures and it was found to vary from 32 to zero dial reading in the range of $45^{\circ} \mathrm{C}$ to $60^{\circ} \mathrm{C}$. Gelwasobservedto break at $45^{\circ} \mathrm{C}$ and $60^{\circ} \mathrm{C}$ in 120 minutes. So, the final temperature was selected as $60^{\circ} \mathrm{C}$ for the application of gel for coal bed methane (CBM) wells. It was observed that higher levels of salinity in water helped in optimum utilization of gel in real time application.
\end{abstract}

Keywords: Bio-diesel, Linear gel, Slick water, Hydro fracturing, Guar polymer gel, Breaker

\section{Introduction}

Hydraulic fracturing deals with pumping of gallons of fluid into oil or gas well at high pressure to induce fractures in the rock formation facilitating the liberation of oil or gas. ${ }^{1,2}$ Until now, drinking water has always been the source of hydro fracturing operation. However, this strategy found to be different problems including water shortage and contamination..$^{3-5}$ Therefore, it is Important to develop a hydro fracturing method with not only recovery of water and decrease the water contamination but also capable to avoid microorganism's contamination. Recently, polymers gel based fracturing methods developed to avoid above mentioned problem. The polymers gel based fracturing fluid undergoes enzymatic attack by the aerobic bacteria present in the base water. ${ }^{6,7}$ Unless controlled, the growth of microorganism will make the polymer as non-functional. Therefore, biocides/bactericides are added to minimize the bacterial contamination in the base water ${ }^{8,9}$ Currently, fossil diesels are normally used in the preparation of linear and cross-link gels, which are environmentally harmful and wasteful of natural resources. ${ }^{10,11}$ Using fossil diesel in the preparation of frac concentration, results in the release of harmful and contami nated carbon dioxide fumes that promotes the global warming condition which is a major drawback. Research reports that vegetable bio-diesel can be used as a substitute for fossil diesel. ${ }^{12,13}$ The findings that were presented suggest that Biodiesel, an alternative eco-friendly fuel synthesized from "Jatropha seed". ${ }^{14}$ This research work explored to develop alternate methods for hydro fracturing process, which are feasible and eco-friendly. Pilot tests were also conducted for the first time by using the bio-diesel as the alternate fuel and are found to be more economical. Successful execution of pilot tests of the frac operations and the fruitful results are detailed. When compared with fossil diesel XLFC, the bio-diesel XLFC shows better and improved results for on-shore and off-shore fracturing operations. ${ }^{15-18}$

\section{Acknowledgments}

None.

\section{Funding \\ None.}

Quick Response Code:

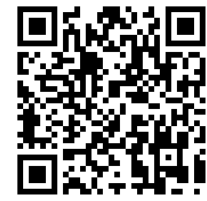

*Corresponding author: Murthy Chavali, Vignan's Foundation for Science, Technology and Research University (VFSTR University; Vignan's University), Vadlamudi, Guntur 522213, Andhra Pradesh, India

Received: 15 December, 2020

Published: 18 January, 2021

Citation: Ramana MRVV, Devaraju S, Chavali M. A Review of Linear Gel Fracturing Fluids. Trends Petro Eng. 2021;1(1):1-2. DOI: 10.53902/TPE.2021.01.000501 


\section{Conflicts of Interest}

Authors declares that there is no conflict of interest.

\section{References}

1. Hyne NJ. Nontechnical Guide to Petroleum Geology, Exploration, Drilling and Production. $3^{\text {rd }}$ ed., Penn Well Corporation, Oklahoma, (2012).

2. Michael BS, Carl TM. Hydraulic fracturing, Taylor \& Francis group, Boca Raton, 2015.

3. Chen W, Maurel O. Experimental study on an alternative oil stimulation technique for tight gas reservoirs based on dynamic shock waves generated by Pulsed Arc Electrohydraulic Discharges. J Petrol Sci Engg. 2012;88:67-74.

4. Corrie EC, Robert MH, Christopher BH. Life cycle water consumption for shale gas and conventional natural gas. Env Sci Tech. 2013; 47:1182911836.

5. Bao Y, Huang $\mathrm{H}, \mathrm{He} \mathrm{D}$, et al. Microbial enhancing coal-bed methane generation potential, constraints and mechanism-A mini-review. J Nat Gas Sci Engg. (2016); 35: 68-78.

6. James GS. Handbook of Hydraulic Fracturing, John Wiley \& sons Inc., New Jersey, 2016; p.150-200.

7. Kahrilas GA, Blotevogel J, Stewart PS, et al. Biocides in Hydraulic Fracturing Fluids: A Critical Review of Their Usage, Mobility, Degradation, and Toxicity. Env Sci Tech. (2015);49:16-32.

8. Vengosh A, Jackson RB, Warner N, et al. Critical Review of the Risks to Water Resources from Unconventional Shale Gas Development and Hydraulic Fracturing in the United States. Env Sci Tech. 2014;48:83348348.

9. Stringfellow WT, Camarillo MK, Domen JK, et al. Identifying chemicals of concern in hydraulic fracturing fluids used for oil production. Env Poll. 2017;220:413-420.
10. Abdulmumin OA, Jianchun G, Shibin W, et al. Hydraulic fracture fluid for gas reservoirs in petroleum engineering applications using sodium carboxy methyl cellulose as gelling agent. J Nat Gas Sci Engg. (2016);32:491-500.

11. Serdyukov SV, Shilova TV, Drobchik AN. Polymeric insulating compositions for impervious screening in rock masses. J Min Sci. 2016;52:826-833.

12. Hoss B, Ebrahim F, Fatemeh B. Hydraulic Fracturing in Unconventional Reservoirs: Theories, Operations, and economic analysis, Gulf professional publishing, United Kingdom, 2017.

13. Ramana Murthy RVV, Murthy C, Naresh KK. Preparation of linear frac concentration with 4-Vinyl-2,6-Dimethoxyphenol. Mater Today: Proc. 2016;3(7):3792-3798.

14. Siddharth J, Sharma MP. Prospects of biodiesel from Jatropha in India: A review. Renew Sust Energ Rev. 2010;14:763-771.

15. Waters G, Dean B, Downie R, et al. Simultaneous hydraulic fracturing of adjacent horizontal wells in the Woodford shale. In SPE Hydraulic Fracturing Technology Conference. Woodlands, Texas. 2009;p.694-715.

16. Xu B, Hill AD, Zhu D, et al. Experimental Evaluation of Guar-Fracture-Fluid Filter-Cake Behaviour. SPE Production \& Operations. 2011;26(04):381387.

17. Yu W, Sepehrnoori K. Optimization of Multiple Hydraulically Fractured Horizontal Wells in Unconventional Gas Reservoirs. Journal of Petroleum Engineering. 2013:1-16.

18. Zhang QB, Zhao J. A Review of Dynamic Experimental Techniques and Mechanical Behaviour of Rock Materials. Rock Mechanics and Rock Engineering. 2014;47(4):1411-1478. 